to these discussions. Meanwhile, women in the SPD who were radicalised by the appearance of the Greens in the Bundestag stepped up their pressure on the party to implement strategies of positive action in respect of women candidates.

Here too there was an outbreak of competition for women's support. The Greens led, pledging that 50\% of its candidates at all levels of elections would be women, as would $50 \%$ of party office holders. In response, the CDU offered to nominate women in proportion to their membership in the party and the SPD promised that, by the 1990 s, half of its candidates would be women. In 1987, a record number of women candidates were nominated and subsequently elected. In 1990, the SPD pledged to enforce a $40 \%$ quota in its party organization by 1994, and the Liberals promised to nominate women in proportion to their membership in the party. Only the CSU refrained from such pledges.

What may we conclude from this case? There is strong evidence that political institutions matter. West
German women out-performed British women despite a later start and a weaker feminist movement. The low West German threshold of representation is the key. All of the other factors were either similar or suggested another outcome. Proportional electoral systems with high district magnitudes offer opportunities to alter party candidate profiles. They tend to be associated with party systems in which party managers can determine candidate selection. When demand for change comes, women candidates may be placed in good places on party lists and that is what West German party managers did.

But this does not mean that feminism does not matter. In both systems, established institutions became carriers of feminist ideas. In both systems, the strongest effects were in the parties in which women organized to pressure the parties from the inside. We may conclude that the institutions of representation matter more than the strength of feminist organization, but feminist organization is also important to the politics of increasing women's political visibility and power.

\section{References}

Kaplan, Gisela. 1992. Contemporary West European Feminism. London: UCL Press \& Allen \& Unwin.

Kolinsky, Eva. 1993. "Party Change and Women's Representation in Unified Germany." In Gender and Party Politics eds. Joni Lovenduski and Pippa Norris, 11346. London: Sage.

Kolinsky, Eva. 1991. "Women's Quotas in West Germany." West European Politics. 14(1).

Lovenduski, Joni and Vicky Randall. 1993. Contemporary Feminist Politics. Oxford: Oxford University Press.

Norris, Pippa. 1993. "Conclusions: Comparing Legislative Recruitment." In Gender and Party Politics, eds. Joni Lovenduski and Pippa Norris, 309-30. London: Sage.

\begin{abstract}
About the Author
Joni Lovenduski is professor of politics at Southampton University. She is author of Women and European Politics, (1986) co-author of Political Reconitment (1994), Contemporary Feminist Politics (1993), and Politics and Society in Eastern Europe (1987). She was co-Director of the British Candidate Study from 1988 to 1992. She was a founding convener of the Standing Group on Women and Politics of the European Consortium for Political Research and of the Women and Politics Group of the Political Studies Association of the UK.
\end{abstract}

\title{
Integrating Women into the Study of European Politics
}

\section{Sonja Elison, Gonzaga University}

Classes on European politics should include women because women represent over $50 \%$ of the population in most Western democratic societies, and their votes are quite consequential. European politicians know this; so should students of political science. If we ignore the influence of women's votes on the strategies of politicians and parties, we distort the reality of democracy. Throughout the 1980s and the 1990s, European political systems responded to women through a variety of demo- cratic mechanisms, such as quotas and party conferences. Integrating gender into the European politics curriculum is essential when covering electoral systems, social movements, party politics (especially of the right), religion, and transitions to democracy. Below, I discuss models for such integration using the kind of cases discussed by Joni Lovenduski. For me, using these cases in the undergraduate classroom has been highly effective.

\section{Exercise 1: Electoral Systems}

For many undergraduates, one of the oddest features of European politics is proportional representation (PR) and its relation to multiparty systems. To help students understand the difference between voting in a majoritarian system and voting in a PR system, I conduct mock elections. The students suggest parties for which they want to vote. When we do a PR system, the students often have a hard time envi- 
sioning anything beyond the Democrats and Republicans, so it may be necessary to suggest some alternatives (the Polish Beer Drinker's Party is usually rather popular with students!). Usually students do not suggest a "women's party," so this is a great time to concentrate on asking the female students in the class for suggestions.

Since I usually teach rather small classes, I allow each of the students to cast up to five votes. As soon as women realize that they may vote for a women's party, it ends up becoming one of the larger ones (about $11-30 \%$ of the vote). This leads into detailed discussion of gender issues which may be stimulated by asking the students to reflect on what the parties should include in their platforms. Let some of the "hams" imagine themselves as party leaders. What would the response of the leader of the socialist party (which undoubtedly has not won a majority of the vote) be to the leader of the women's party? Would he or she be willing to envisage a quota system, a coalition, or powersharing within the party? Ask the students (especially those who voted for the small parties) how they feel about the election results. This works especially well if you can do a mock majority-style election, so students can contrast their feelings after each type of election. Hopefully, this will produce active debate about representation in democratic elections, among other topics.

To ground the exercise in reality, you can use the empirical case which Joni Lovenduski discussed above to illustrate how women (an underrepresented group) might devise different strategies within different systems. Several good sources for reading are available, including $G e n$ der and Party Politics edited by Joni Lovenduski and Pippa Norris (1994) and Eva Kolinsky "Political Participation and Parliamentary Careers" in West European Politics (January 1991: 56-72). A nice hand-out for students is "Women, Power, and Politics: The Norwegian Experience" by Irene Garland in Scandinavian Review (Winter 1991). It is often reprinted in Annual Edition's Comparative Politics, published by Dushkin. Finally, an interesting chapter to read is Audur Styrkarsdottir's about Iceland's Women's Party, in Drude Dahlerup's edited volume The New Women's Movement (1986).

\section{Exercise 2: Social Movements}

Since women's movements and environmental movements are two of the most important social movements in post-World War II Europe, it is worthwhile to discuss their goals, the institutional contexts that shapes them, and the impact of these movements. One approach is to ask students what kind of images come to mind when they think about social movements. Ask them about what they think the women's movement was about, and what they think a "feminist" is. It is important to discuss the goals of these movements, and to encourage students to think about them. Be sure to note those goals that students volunteer and return to them later. The differences in goals between social movements and interest groups, and the resulting differences in strategies can be discussed using women and the Greens as examples.

Given that some of the goals will be legislative in nature (e.g., equal pay laws, provision of child care by the state, equal opportunities for education, freedom of reproductive choice), the question of the relationship between the movement and established political parties and unions will be an important issue. The debate over these relationships within many women's movements paralleled the well-known distinction between "realists" or "pragmatists" within many Green parties. For example, the women's movement in the United States is split between those who favored integration and those who favored autonomy. The same split occurred in Germany. Two excellent references for these cases are the chapter on the United States by Anne N. Costain and W. Douglas Costain and the chapter on Germany by Myra Marx Ferree in The Women's Movements of the United States and Western Europe, edited by Mary Fainsod Katzenstein and Carol McClurg Mueller (1987). By contrast, Britain's more closed political system did not pose as much a temp- tation to pragmatists (see Joyce Gelb's chapter in the same book). These three cases demonstrate that while stated goals are similar, the political institutional context offers varying opportunities for access and influence, thus affecting strategies preferred by the women in these movements. The strategies which feminists choose within different contexts result in varying levels of success, whether measured by levels of representation or by successful legislative or policy outcomes. An excellent reference for the latter is Jane Jenson, Elisabeth Hagen, and Ceallaigh Reddy's book The Feminization of the Labour Force (1988).

To introduce an interesting twist, you might ask students if they think it necessary to continue with a movement once women are in parliament and parties. In a number of cases (for instance, Russia, Hungary, and Brazil), the number of elected women decreased drastically after democratization. So, the connection between women in institutions and those at the grass roots, the connection provided by the movement, is fundamental to the power of women who are integrated into the political establishment. For a discussion of the United States case, see Susan Carroll's chapter in Women Transforming Politics edited by Jill Bystydzienski (1994); for Brazil, see Sonia Alvarez' chapter on Brazil in The Women's Movement in Latin America, edited by Jane S. Jaquette (1994), and or Russia, see Mary Buckley's Perestroika and Soviet Women, (1992).

\section{Exercise 3: German Unification}

Essential to any course on European Politics is a segment on the velvet revolutions of 1989 in Central and Eastern Europe. The information below relates specifically to German unification, but the same trends were apparent across the former "Eastern Bloc". Ask students whether the transition was good or bad for these countries. Were they winners or losers? Students often assume the transition was good, but the example of women's political representation and policy helps to challenge 


\begin{tabular}{|c|c|c|c|}
\hline \multicolumn{4}{|c|}{$\begin{array}{l}\text { The Status of Women in Germany: } \\
\text { East, West and after Unification }\end{array}$} \\
\hline & West & East & Unity \\
\hline Pensions (for mothers) & 1 year & 9 years & 1 year \\
\hline Wages & $60-70 \%$ of male & $80 \%$ of male & \\
\hline $\begin{array}{l}\text { Women working } \\
\text { (1991) }\end{array}$ & $63 \%$ & $90 \%$ & \\
\hline Unemployment & $\begin{array}{l}10 \% \text { women } \\
8.7 \% \text { total }(1988)\end{array}$ & Unknown & $\begin{array}{l}1 \text { year later: } 60 \% \text { of } \\
\text { women are unemployed }\end{array}$ \\
\hline Child Care & $\begin{array}{l}5 \% \text { up to age } 3 \\
70 \% \text { ages } 4-5 \\
85 \% \text { ages } 5-6\end{array}$ & almost universal & promises \\
\hline Abortion & Highly restricted & Free and legal & $\begin{array}{l}2 \text { years of dispute, } \\
\text { now highly restricted }\end{array}$ \\
\hline Parental Leave & $\mathrm{M} / \mathrm{F}$ : up to 2 years & F: $1-3$ years & $\mathrm{M} / \mathrm{F}$ : up to 2 years \\
\hline Children & $\begin{array}{l}\text { Most couples } \\
\text { have } 1-2\end{array}$ & $\begin{array}{l}90 \% \text { of couples } \\
\text { have } 1\end{array}$ & \\
\hline Child Allowances & $25 \%$ of cost & $70 \%$ of cost & \\
\hline Social Security & $40-50 \%$ of men's & About $90 \%$ of men's & \\
\hline Women in Parliament & 1983: $10 \%$ & $32 \%$ & $20 \%$ \\
\hline
\end{tabular}

this assumption and to give students a better sense of reality.

Present students with the following chart drawn principally from Ute Gerhard's article "German Women and the Social Costs of Unification" in German Politics and Society, (Winter 1991-1992), special issue on Germany and Gender; and the chapter by Eva Kolinsky in Developments in German Politics, edited by Gordon Smith, William E. Paterson, Peter H. Merkl, and Stephen Padgett (1992).

Have the students read Gerhard's article, and then explain the chart. Ask students who the winner is now. As these works point out, the state made it easier for women to have children in the East. Since paid employment was less highly valued than it was in West Germany, a much higher value was placed on love and family than on career advancement. During our workshop, Dorothee Wierling, University of Washington, pointed out that in a survey commissioned in the Eastern part of Germany, "love" as a value ranked in first place, while "climbing up the career ladder" ranked sixteenth.

Whether women were winners or losers in unification has been a hotly debated issue in Germany (the aforementioned issue of German Politics and Society is a good reference piece on this debate). Many see the short-term negative impact that unification has had upon women in East Germany. But over the long term, these women will benefit from the overall im- provement in living conditions. In addition, young East German women are more interested in career opportunities than the previous generation. Nonetheless, it is instructive to ask your students how they would feel about unification if they were East Germans.

\section{Conclusion}

The study of gender is an integral part of the research agenda of political science; it should therefore be seen as an integral part of the curriculum. I have attempted to demonstrate a number of ways in which it can be integrated into courses on European politics in a manner that is both stimulating and intellectually enriching. The exercises I have described can help students understand that gender is a concept that underpins the modern political system just as other areas that are given wide coverage in popular textbooks. These exercises are modular, and can be incorporated at minimal cost and disruption to existing syllabi. Hopefully, they can engage students on a personal level and help them relate their own experiences to the more analytical points that arise from coverage of women and politics.

\section{About the Author}

Sonja Elison is an assistant professor in the department of political science at Gonzaga University.

\section{Integrating Gender Into the Political Science Curriculum: Challenges, Pitfalls, and Opportunities}

\section{Christine Di Stefano, University of Washington}

The relationship between gender and politics is both obvious and elusive. The term "gender" refers to socially constructed and politically enforced notions of what it means to be male or female. Gendered notions acquire their plausibility and force by claiming to represent a prepolitical universe of gendered mean- ings and social arrangements. This mythical universe serves, in turn, to legitimize gender norms. Gender is most obviously political in the sense that it shapes the opportunities and liabilities of gender-coded subjects. But it is also political because it has the power to impose meaning and value upon our activities and social relationships and to deflect attention from the politics of meaning. ${ }^{1}$

The elusiveness of the politicsgender connection derives from its very success as a political formation. To the extent that gender is assumed to be an emanation of "nature" rather than an artifact of "culture," its politicalness is rendered invisible. 